Supplement of Biogeosciences, 14, 3549-3560, 2017

https://doi.org/10.5194/bg-14-3549-2017-supplement

(C) Author(s) 2017. This work is distributed under

the Creative Commons Attribution 3.0 License.

(c) (1)

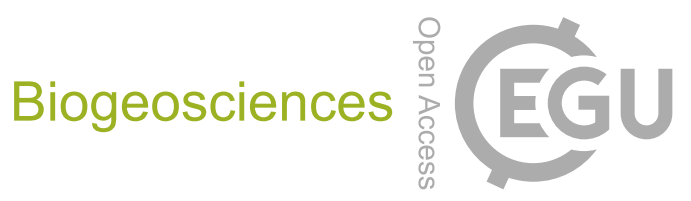

Supplement of

\title{
Daily variation in net primary production and net calcification in coral reef communities exposed to elevated $p \mathrm{CO}_{2}$
}

Steeve Comeau et al.

Correspondence to: Steeve Comeau (steeve.comeau@uwa.edu.au)

The copyright of individual parts of the supplement might differ from the CC BY 3.0 License. 
Supplementary Table 1: Parameters of the hyperbolic tangent functions describing the relationship between community net photosynthesis $\left(P_{\text {net }}\right)$ in the light and PAR in three coral reef communities representing the back reef of Mo'orea, the back reef of $\mathrm{O}$ 'ahu, and the fore reef of Mo'orea. Communities were incubated under ambient $\mathrm{pCO}_{2}(\sim 400 \mu \mathrm{atm})$ and elevated $\mathrm{pCO}_{2}(\sim 1200 \mu \mathrm{atm})$. Parameters of the hyperbolic function are the maximum rate $\left(P_{\text {net } \max }\right)$, the slope of the initial portion of the relationship $(\alpha)$, and the intercept $\left(C_{0}\right)$.

\begin{tabular}{lllll} 
Experiment & Treatment & $\boldsymbol{P}_{\text {net } \max }$ & $\boldsymbol{\alpha}$ & \multicolumn{1}{l}{$\boldsymbol{C}_{\boldsymbol{o}}$} \\
\hline Moorea - back reef & Ambient & $29.7 \pm 3.9$ & $0.16 \pm 0.05$ & $-16.0 \pm 3.9$ \\
& Elevated & $26.7 \pm 3.4$ & $0.11 \pm 0.03$ & $-13.0 \pm 3.4$ \\
& & & & \\
\hline Oahu - back reef & Ambient & $33.9 \pm 4.1$ & $0.05 \pm 0.01$ & $-4.0 \pm 2.0$ \\
& & & & \\
& Elevated & $32.9 \pm 4.1$ & $0.06 \pm 0.01$ & $-5.5 \pm 2.2$ \\
\hline Moorea - fore reef & Ambient & $6.5 \pm 2.5$ & $0.02 \pm 0.01$ & $2.3 \pm 1.9$ \\
& & & & \\
& Elevated & $6.7 \pm 2.1$ & $0.03 \pm 0.02$ & $0.6 \pm 1.7$
\end{tabular}

Supplementary Table 2: Parameters of the hyperbolic tangent functions describing the relationship between community net calcification $\left(G_{\text {net }}\right)$ in the light and PAR in three coral reef communities representing the back reef of Mo'orea, the back reef of O'ahu, and the fore reef of Mo'orea. Communities were incubated under ambient $\mathrm{pCO}_{2}(\sim 400 \mu \mathrm{atm})$ and elevated $\mathrm{pCO}_{2}(\sim 1200 \mu \mathrm{atm})$. Parameters of the hyperbolic function are the maximum rate $\left(G_{\text {net } \max }\right)$, the slope of the initial portion of the relationship $(\alpha)$, and the intercept $\left(C_{0}\right)$.

\begin{tabular}{lllll}
\hline Experiment & Treatment & $\boldsymbol{G}_{\text {net } \max }$ & $\boldsymbol{\alpha}$ & $\boldsymbol{C}_{\boldsymbol{o}}$ \\
\hline Moorea - back reef & Ambient & $7.0 \pm 0.6$ & $0.02 \pm 0.005$ & $1.25 \pm 0.7$ \\
& Elevated & $6.2 \pm 0.6$ & $0.02 \pm 0.004$ & $-0.5 \pm 0.6$ \\
& & & & \\
\hline Oahu - back reef & Ambient & $5.6 \pm 0.9$ & $0.03 \pm 0.01$ & $4.8 \pm 0.9$ \\
& Elevated & $5.9 \pm 1.4$ & $0.009 \pm 0.005$ & $3.7 \pm 1.0$ \\
& & & & \\
\hline Moorea - fore reef & Ambient & $-5.0 \pm 0.9$ & $0.01 \pm 0.00$ & $2.8 \pm 0.5$ \\
& & & & $0.6 \pm 0.5$ \\
& Elevated & $-5.4 \pm 0.7$ & $0.02 \pm 0.0$ & 0.0 \\
\hline
\end{tabular}

